\title{
Thiocapsa litoralis sp. nov., a new purple sulfur bacterium from microbial mats from the White Sea
}

\author{
Nataliya N. Puchkova, ${ }^{1}$ Johannes F. Imhoff ${ }^{2}$ and Vladimir M. Gorlenko'
}

Author for correspondence: Johannes F. Imhoff. Tel: +49 431 6973850. Fax: +49 431565876

e-mail: jimhoff@ifm.uni-kiel.de

1 Institute of Microbiology, Russian Academy of Sciences, pr. 60-letiya Oktyabrya 7 k. 2, Moscow, 117811 Russia

2 Abteilung Marine Mikrobiologie, Institut für Meereskunde Kiel, 24105 Kiel, Germany

\begin{abstract}
A new phototrophic purple sulfur bacterium, isolated from benthic microbial mats from the White Sea littoral zone, is described. Individual cells were spherical, non-motile and lacked gas vesicles. In pure cultures cells appeared in regular platelet-like arrangements of four, eight or sixteen cells. Cell division occurred inside a common envelope, surrounded by a thick capsule. Internal photosynthetic membranes were of the vesicular type. The colour of cell suspensions was pink to rose-red. Bacteriochlorophyll $a$ and carotenoids of the spirilloxanthin series were found as photosynthetic pigments. Under anoxic conditions in the light, photolithoautotrophic growth occurred with sulfide, thiosulfate, sulfite and elemental sulfur as electron donors. Sulfur globules were stored as an intermediary oxidation product and were visible microscopically inside the cells. In the presence of sulfide and bicarbonate, photomixotrophic growth occurred with a number of organic substrates. Sulfate could serve as sole assimilatory source of sulfur.

Chemolithoautotrophic growth in the dark was possible with sulfide and thiosulfate as electron donors. Optimum growth occurred in the presence of $1 \% \mathrm{NaCl}$, at pH 6.5 and at $30{ }^{\circ} \mathrm{C}$. The DNA base composition of the type strain, BM5 $^{\top}$, was $64.0 \mathrm{~mol} \% \mathrm{G}+\mathrm{C}$. According to 165 rDNA sequence information and DNA-DNA hybridization, the new isolate clearly belongs to the genus Thiocapsa, but is sufficiently different from other recognized Thiocapsa species to be described as a new species of this genus for which the name Thiocapsa litoralis sp. nov. is proposed. The type strain is BM5 (= ATCC 700894).
\end{abstract}

Keywords: phototrophic purple bacteria, Chromatiaceae, Thiocapsa litoralis

\section{INTRODUCTION}

Traditionally, simple phenotypic characteristics such as pigment composition, type of internal membrane structures, form and size of cells, motility, presence of gas vesicles and location of sulfur globules were of major importance for differentiation of genera and species of the phototrophic purple bacteria (Winogradsky, 1888; Imhoff, 1995; Pfennig \& Trüper, 1974, 1989). However, study of $16 \mathrm{~S}$ rDNA sequences of members of the Chromatiaceae demonstrated that morphological properties in themselves are not sufficient for a systematic classification of these bac-

The EMBL accession number for the $16 \mathrm{~S}$ rDNA sequence of strain $B \mathrm{BM}^{\top}$ is AJ24772. teria (Imhoff et al., 1998). Although non-motile, spherical cells without gas vesicles traditionally have been a characteristic determinative feature of Thiocapsa, this property is indeed present in phylogenetically distinct bacteria that have recently been excluded from the genus, namely Thiococcus pfennigii and Thiohalocapsa halophila (Imhoff et al., 1998). The presence of gas vesicles and also the formation of typical cell aggregates are of questionable taxonomic importance. The ability to form platelets is a peculiarity of two species that also contain gas vesicles, Thiopedia rosea (Pfennig, 1973; Eichler \& Pfennig, 1991) and Thiolamprovum pedioforme (formerly 'Amoebobacter pedioformis'; Eichler \& Pfennig, 1986), but has also been described for strains assigned to Thiocapsa roseopersicina (see Pfennig \& Trüper, 1989).

Genetic studies of the spherical and non-motile photo- 
trophic purple sulfur bacteria revealed a close relationship between Thiocapsa roseopersicina, the type species of this genus, and bacteria that were previously classified in the genus Amoebobacter. Consequently, these species were transferred to the genus Thiocapsa and are now known as Thiocapsa rosea and Thiocapsa pendens (Guyoneaud et al., 1998). The genus Thiocapsa at present includes species with and without gas vesicles and this property is no longer recognized as being genus-specific.

Microscopic study of natural samples from microbial mat communities from the White Sea littoral zone revealed numerous flat, rectangular platelets composed of 16, 32 and more cells without gas vesicles. Pure cultures of a phototrophic purple bacterium (strain $\mathrm{BM} 5^{\mathrm{T}}$ ) with such a morphology were isolated from these samples. The present study describes the morphological and physiological characteristics and gives a taxonomic description of the new bacterium. On the basis of morphological, physiological and biochemical properties, as well as 16S rDNA sequence analysis, the new bacterium is recognized and described as a new species of the genus Thiocapsa. The name Thiocapsa litoralis sp. nov. is proposed.

\section{METHODS}

Source of organisms. Strain $\mathrm{BM}^{\mathrm{T}}$ was isolated from a microbial mat community from the White Sea, located in a natural, shallow littoral beach, which is only periodically covered by seawater.

Media and growth conditions. Enrichments and pure cultures were grown in Pfennig's medium (Pfennig \& Trüper, 1992) containing (per litre): $15 \mathrm{~g} \mathrm{NaCl}, 1.5 \mathrm{~g} \mathrm{NaHCO}_{3}, 0.5 \mathrm{~g}$ $\mathrm{Na}_{2} \mathrm{~S} .9 \mathrm{H}_{2} \mathrm{O}, 25 \mu \mathrm{g}$ vitamin $\mathrm{B}_{12}, 1 \mathrm{ml}$ trace element solution SL12 (Pfennig \& Trüper, 1992), $1.0 \mathrm{~g}$ sodium acetate and $0.5 \mathrm{~g}$ sodium thiosulfate. The $\mathrm{pH}$ was adjusted to $7 \cdot 2$. Cultures were incubated at $25^{\circ} \mathrm{C}$ and $2000 \mathrm{~lx}$, which is approximately equivalent to $38 \mu \mathrm{mol}$ photons $\mathrm{m}^{-2} \mathrm{~s}^{-1}$ light intensity, as measured with a Lux 3 luxmeter (Gidrometeopribor). Liquid cultures were grown in 30 and $50 \mathrm{ml}$ screw-cap bottles. Pure cultures were obtained by repeated transfer of separate colonies in agar dilution series. Purity was checked by microscopic examination. Utilization of carbon sources and electron donors was tested using substrates at a concentration of $1 \mathrm{~g} \mathrm{l}^{-1}$. Chemolithoautotrophic growth was tested in agar tubes incubated in the dark and with a headspace of air. Growth was monitored as optical density at $650 \mathrm{~nm}$ after complete oxidation of elemental sulfur by the cultures using uninoculated culture medium as a control.

Pigment analysis. Absorption spectra of suspensions of living cells were measured in $50 \%$ glycerol using $1 \mathrm{~cm}$ cuvettes in a SF-56 spectrophotometer (LOMO).

Light and electron microscopy. Intact cells were examined in a phase-contrast microscope. For electron microscopy, cells were fixed with $1 \%$ osmium tetroxide, contrasted with $1 \%$ uranyl acetate and embedded in Epon 812.

Genetic properties. DNA was isolated by the method of Marmur (1961) and the DNA base composition was determined by thermal denaturation (by A. M. Lysenko, Institute of Microbiology, Moscow, Russia) according to Owen et al. (1969). Cell material for 16S rDNA sequencing was taken from 1-2 $\mathrm{ml}$ of well-grown liquid cultures. DNA was extracted and purified by using the Qiagen genomic DNA buffer set. PCR amplification and $16 \mathrm{~S}$ rDNA sequencing was done as described previously (Imhoff et al., 1998). Recombinant Taq polymerase was used for PCR, which was started with the primers 5'-GTTTGATCCTGGCTCAG-3' and 5'-TACCTTGTTACGACTTCA-3' (positions 11-27 and 1489-1506, respectively, according to the Escherichia coli $16 \mathrm{~S}$ rRNA numbering of the International Union of Biochemistry). Sequences were obtained by cycle sequencing with the SequiTherm sequencing kit (Biozym) and the chain termination reaction (Sanger et al., 1977) using an automated laser fluorescence sequencer. Sequences were aligned using the CLUSTAL W program (Thompson et al., 1994). The alignment length was from position 29 to 1381 according to the E. coli numbering. The distance matrix was calculated on the basis of the algorithm according to Jukes \& Cantor (1969) with the DNADIST program within the PHYLIP package (Felsenstein, 1989). The FITCH program in the PHYLIP package fitted the tree to the evolutionary distances.

\section{RESULTS}

\section{Isolation and culture}

Platelet-forming, spherical purple sulfur bacteria were found as a permanent component of microbial mat communities in lagoons from the White Sea littoral zone and also from the river Nilmo estuary. Phototrophic micro-organisms associated with these mats resembled species of the genera Thiocapsa, Chromatium, Thiocystis, Prosthecochloris, Beggiatoa, Oscillatoria and 'Merismopedia'. The salinity in the littoral zone was between 1.5 and $15 \mathrm{~g} \mathrm{l}^{-1}$, the $\mathrm{pH}$ was 7.4-7.9 and the temperature varied between 10 and $16^{\circ} \mathrm{C}$. Microbial communities developed at the surface of reduced and sulfide-containing sediments and had a layered structure. Typically, bacteria such as the new isolate were found at the lowest position of the phototrophic communities. Laboratory studies confirmed that regular cell aggregates were formed at light intensities lower than 2000 lx (approx. $38 \mu \mathrm{mol}$ photons $\mathrm{m}^{-2} \mathrm{~s}^{-1}$ ). In contrast to the natural situation where platelets of 16 and 32 cells were dominant, in culture, platelets with 4,8 and eventually 16 cells were observed. Over 5 years of cultivation in the laboratory, strain $\mathrm{BM} 5^{\mathrm{T}}$ retained the ability to form tetrads and larger platelets.

Strain $\mathrm{BM} 5^{\mathrm{T}}$ was isolated from a deep-agar dilution series that had been inoculated with a pink-coloured sample of a microbial mat from the White Sea littoral zone. After incubation for 1 week in the light, pink colonies were picked and studied microscopically. The colonies contained platelet-like aggregates. Pure cultures were obtained using isolated colonies as inoculum for several further deep-agar dilution series. After purity was achieved, one pure colony was transferred into liquid medium and this culture was used for further studies. 

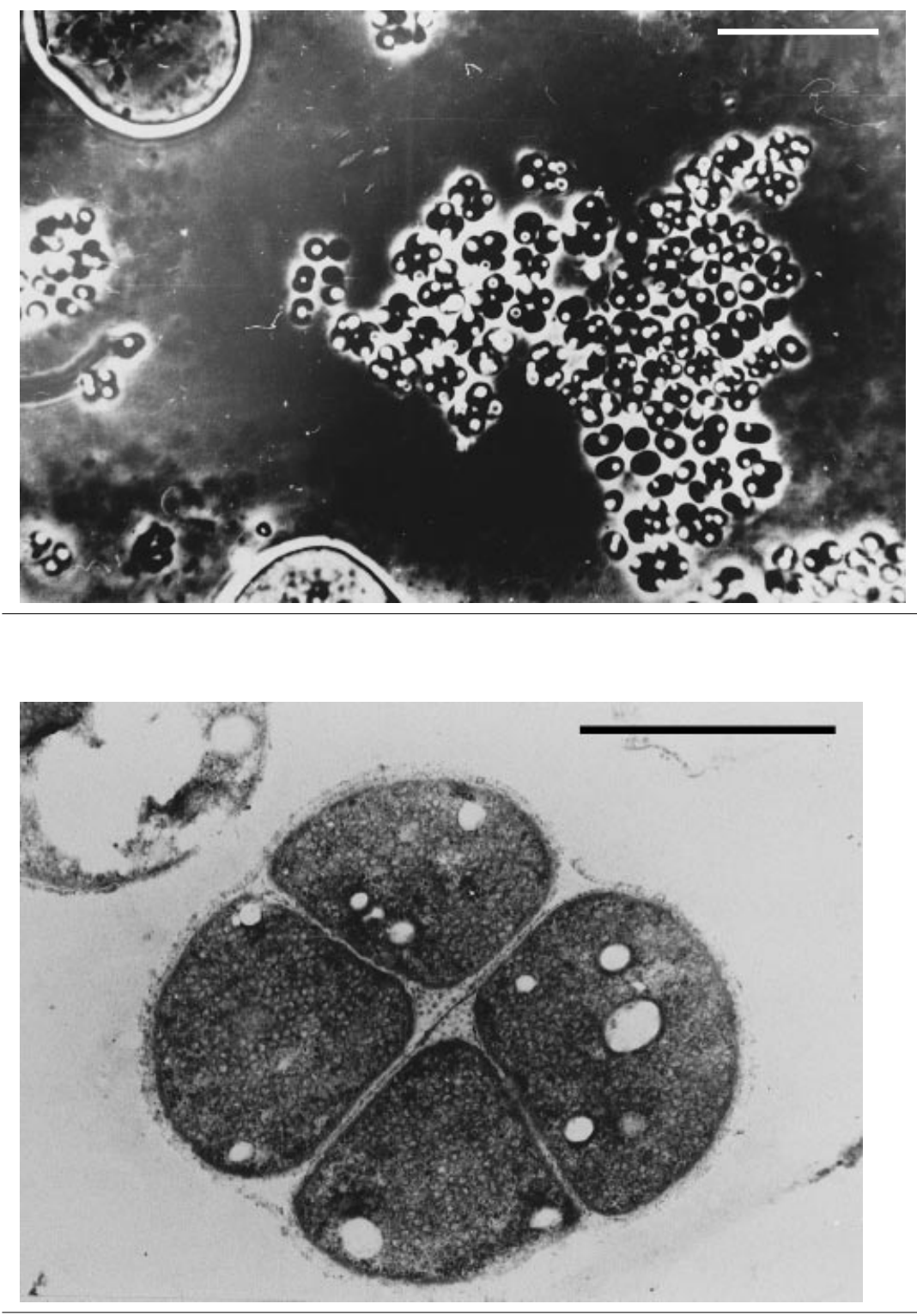

Fig. 1. Phase-contrast photomicrograph of strain $\mathrm{BM}^{\top}$ showing cells grown under optimal growth conditions, some containing internal sulfur globules. Bar, $10 \mu \mathrm{m}$.

\section{Morphology and fine structure}

Individual cells of strain $\mathrm{BM}^{\mathrm{T}}$ were non-motile, spherical and $1 \cdot 5-2 \cdot 5 \mu \mathrm{m}$ in diameter. Cells were arranged in flat, rectangular platelets, most of which consisted of 4, 8 and sometimes 16 cells, surrounded by a common envelope and a thick capsule (Fig. 1). Formation of regular cell aggregates in laboratory experiments took place when the light intensity was lower than 2000 lx (approx. $38 \mu \mathrm{mol}$ photons $\mathrm{m}^{-2} \mathrm{~s}^{-1}$ ). At high light intensity, cells did not form aggregates, but large, single cyst-like cells appeared, surrounded by a dense, thick capsule. Cells of strain $\mathrm{BM} 5^{\mathrm{T}}$ stained Gram-negative and did not contain gas vesicles. Light field microscopy showed globules of elemental sulfur, located inside the cells (Fig. 1). Examination of ultrathin sections of strain $\mathrm{BM}^{\mathrm{T}}$ by electron microscopy revealed an internal membrane system of the vesicular type (Fig. 2).

\section{Physiological properties}

Strain BM5 ${ }^{\mathrm{T}}$ grew well in Pfennig's medium with $\mathrm{NaCl}$ concentrations between 0.5 and $2.5 \%$ under anoxic conditions in the light, or under microoxic conditions in the dark. Photolithoautotrophic growth occurred with hydrogen sulfide, thiosulfate, sulfite and elemental sulfur as electron donors. Globules of elemental sulfur were stored inside the cells as an intermediary oxidation product. In the presence of carbon dioxide and sulfide, photoassimilation of acetate, propionate, butyrate, valerate, pyruvate, lactate, malate, succinate, fumarate, glucose, fructose, yeast extract and Casamino acids was possible (Table 1). The new isolate was capable of photoorganotrophic growth with acetate in the absence of a reduced sulfur compound and under these conditions used sulfate as sole source of cellular sulfur. Chemolithoautotrophic growth occurred under microoxic conditions in the dark using 
Table 1. Characteristic properties for differentiation between strain $B M 5^{\top}$ and related purple sulfur bacteria

All species possess spherical, motile cells, and use sulfide, sulfur, acetate and pyruvate. + , Substrate used or property present in most strains; -, substrate not used or property absent; +/ - property variable with different strains; ND, no data available.

\begin{tabular}{|c|c|c|c|c|c|c|}
\hline Character & $\begin{array}{c}\text { Thiocapsa } \\
\text { litoralis } \mathbf{B M 5}^{\mathrm{T}}\end{array}$ & $\begin{array}{c}\text { Thiocapsa } \\
\text { roseopersicina }\end{array}$ & $\begin{array}{l}\text { Thiocapsa } \\
\text { pendens }\end{array}$ & $\begin{array}{l}\text { Thiocapsa } \\
\text { rosea }\end{array}$ & $\begin{array}{c}\text { Thiolamprovum } \\
\text { pedioforme }\end{array}$ & $\begin{array}{l}\text { Thiopedia } \\
\text { rosea }\end{array}$ \\
\hline Cell diameter $(\mu \mathrm{m})$ & $1 \cdot 5-2 \cdot 5$ & $1 \cdot 2-3 \cdot 0$ & $1 \cdot 5-2 \cdot 0$ & $2 \cdot 0-3 \cdot 0$ & $2 \cdot 0$ & $2 \cdot 0-2 \cdot 5$ \\
\hline Gas vesicles & - & - & + & + & + & + \\
\hline Aggregate formation & $\begin{array}{l}\text { Tetrads, regular } \\
\text { platelets }\end{array}$ & $\begin{array}{c}\text { Tetrads, small } \\
\text { irregular aggregates }\end{array}$ & $\begin{array}{l}\text { Irregular } \\
\text { aggregates }\end{array}$ & $\begin{array}{l}\text { Irregular } \\
\text { aggregates }\end{array}$ & Platelets & Platelets \\
\hline $\begin{array}{l}\text { Colour of cell } \\
\text { suspensions }\end{array}$ & Pink to rose-red & Pink to rose-red & Pink to rose-red & Pink to rose-red & Pink to rose-red & Purple-red \\
\hline Carotenoid group* & $\mathrm{sp}$ & $\mathrm{sp}$ & $\mathrm{sp}$ & $\mathrm{sp}$ & $\mathrm{sp}$ & ok \\
\hline $\begin{array}{l}\text { DNA G }+\mathrm{C} \text { content } \\
(\mathrm{mol} \%)\end{array}$ & $64 \cdot 0$ & $63 \cdot 3-66 \cdot 3$ & $65 \cdot 3$ & $64 \cdot 3$ & $65 \cdot 5$ & $62 \cdot 5-63 \cdot 5$ \\
\hline $\begin{array}{l}\text { Vitamin } \mathrm{B}_{12} \\
\text { requirement }\end{array}$ & + & - & + & + & - & - \\
\hline Sulfate assimilation & + & + & - & - & - & - \\
\hline $\begin{array}{l}\text { Chemoautotrophic } \\
\text { growth }\end{array}$ & + & + & - & + & + & - \\
\hline pH optimum & $6 \cdot 5$ & $7 \cdot 3$ & $6 \cdot 7-7 \cdot 5$ & $6 \cdot 7-7 \cdot 5$ & $7 \cdot 4-7 \cdot 6$ & $7 \cdot 3-7 \cdot 5$ \\
\hline $\mathrm{NaCl}$ optimum (\%) & 1 & None & None & None & None & None \\
\hline \multicolumn{7}{|l|}{ Substrates used $: \dagger$} \\
\hline Hydrogen & ND & + & - & - & - & - \\
\hline Thiosulfate & + & + & + & + & + & - \\
\hline Formate & - & - & - & - & - & ND \\
\hline Propionate & + & $+/-$ & + & + & - & - \\
\hline Butyrate & + & - & - & - & - & + \\
\hline Valerate & + & ND & - & - & - & + \\
\hline Lactate & + & $+/-$ & + & + & + & - \\
\hline Fumarate & + & + & - & - & - & $+/-$ \\
\hline Succinate & + & + & - & - & - & $+/-$ \\
\hline Malate & + & + & + & $+/-$ & - & $+/-$ \\
\hline Fructose & + & + & - & + & - & $+/-$ \\
\hline Glucose & + & - & + & - & - & + \\
\hline Ethanol & - & - & ND & - & - & - \\
\hline Propanol & ND & - & ND & - & - & - \\
\hline Glycerol & - & + & - & - & - & - \\
\hline Glycolate & ND & - & ND & ND & - & - \\
\hline Crotonate & ND & ND & ND & ND & - & - \\
\hline Casamino acids & + & ND & ND & ND & - & - \\
\hline
\end{tabular}

* sp, Spirilloxanthin; ok, okenone.

$\dagger$ The following substrates were tested but were not utilized by strain BM5 ${ }^{\mathrm{T}}$ : caprylate, tartrate, formate, ascorbate, asparaginate, benzoate, malonate, citrate, maltose, galactose, mannitol, sorbitol, glycerol, methanol and ethanol.

hydrogen sulfide and thiosulfate as electron donors and with elemental sulfur as an intermediary product. Best growth was obtained at $\mathrm{pH} 6 \cdot 5,30^{\circ} \mathrm{C}$ and a $\mathrm{NaCl}$ concentration of $1 \%$. Vitamin $\mathrm{B}_{12}$ was required as a growth factor.

\section{Photosynthetic pigments}

Photolithotrophically grown cultures of strain BM5 ${ }^{\mathrm{T}}$ were of a pink to red colour. Absorption spectra of cell suspensions exhibited in vivo absorption maxima at
375, 484, 516, 552, 590, 800, 855 and $896 \mathrm{~nm}$ (Fig. 3). These spectra indicate the presence of bacteriochlorophyll $a$ and are preliminary evidence for carotenoids of the spirilloxanthin series (Pfennig \& Trüper, 1992).

\section{Genetic properties}

The phylogenetic position of strain $\mathrm{BM} 5^{\mathrm{T}}$ relative to that of other purple bacteria was examined by $16 \mathrm{~S}$ rDNA sequencing. The data obtained showed that 


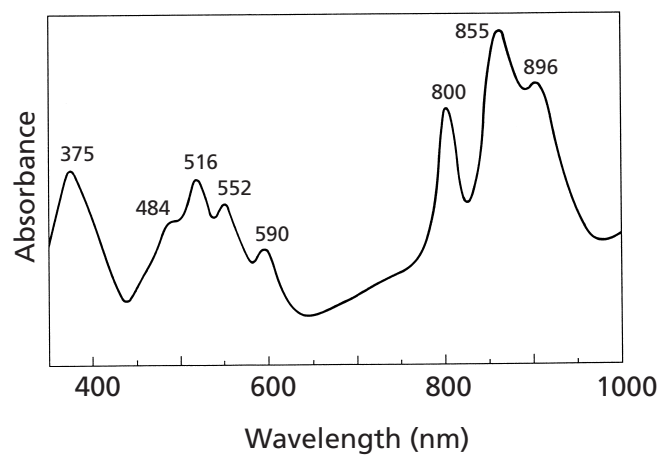

Fig. 3. Absorption spectrum of living cells of strain $B M 5^{\top}$ grown photoautotrophically with sulfide at approximately $38 \mu \mathrm{mol}$ photons $\mathrm{m}^{-2} \mathrm{~s}^{-1}$ light intensity. The presence of bacteriochlorophyll $a$ and core and peripheral light harvesting complexes is indicated by the absorption maxima at 800,855 and $896 \mathrm{~nm}$.

strain $\mathrm{BM} 5^{\mathrm{T}}$ clearly belongs in the genus Thiocapsa, but is distinct from Thiocapsa roseopersicina and other Thiocapsa species (Fig. 4). The highest sequence similarities were found to type strains of Thiocapsa pendens $(96.6 \%)$ and Thiocapsa roseopersicina $(95.4 \%)$, with values of approximately $94-95 \%$ to other strains and species of this group. DNA purified from strain $\mathrm{BM}^{\mathrm{T}}$ had a base composition of $64.0 \mathrm{~mol} \% \mathrm{G}+\mathrm{C}$ as determined by thermal denaturation. DNA-DNA hybridization with Thiocapsa roseopersicina strains DSM $217^{\mathrm{T}}$, OP-3 and BBS revealed a homology of not more than $10-13 \%$ between strain $\mathrm{BM} 5^{\mathrm{T}}$ and the other strains.

\section{DISCUSSION}

The recognition of genetic relationships between members of the Chromatiaceae on the basis of $16 \mathrm{~S}$ rDNA sequences demonstrated that morphological and physiological properties are not sufficient for the classification of the species and may even be misleading in some instances (Imhoff et al., 1998). Sequence data and also DNA-DNA hybridization studies are required to obtain a reliable background for separation of closely related species.

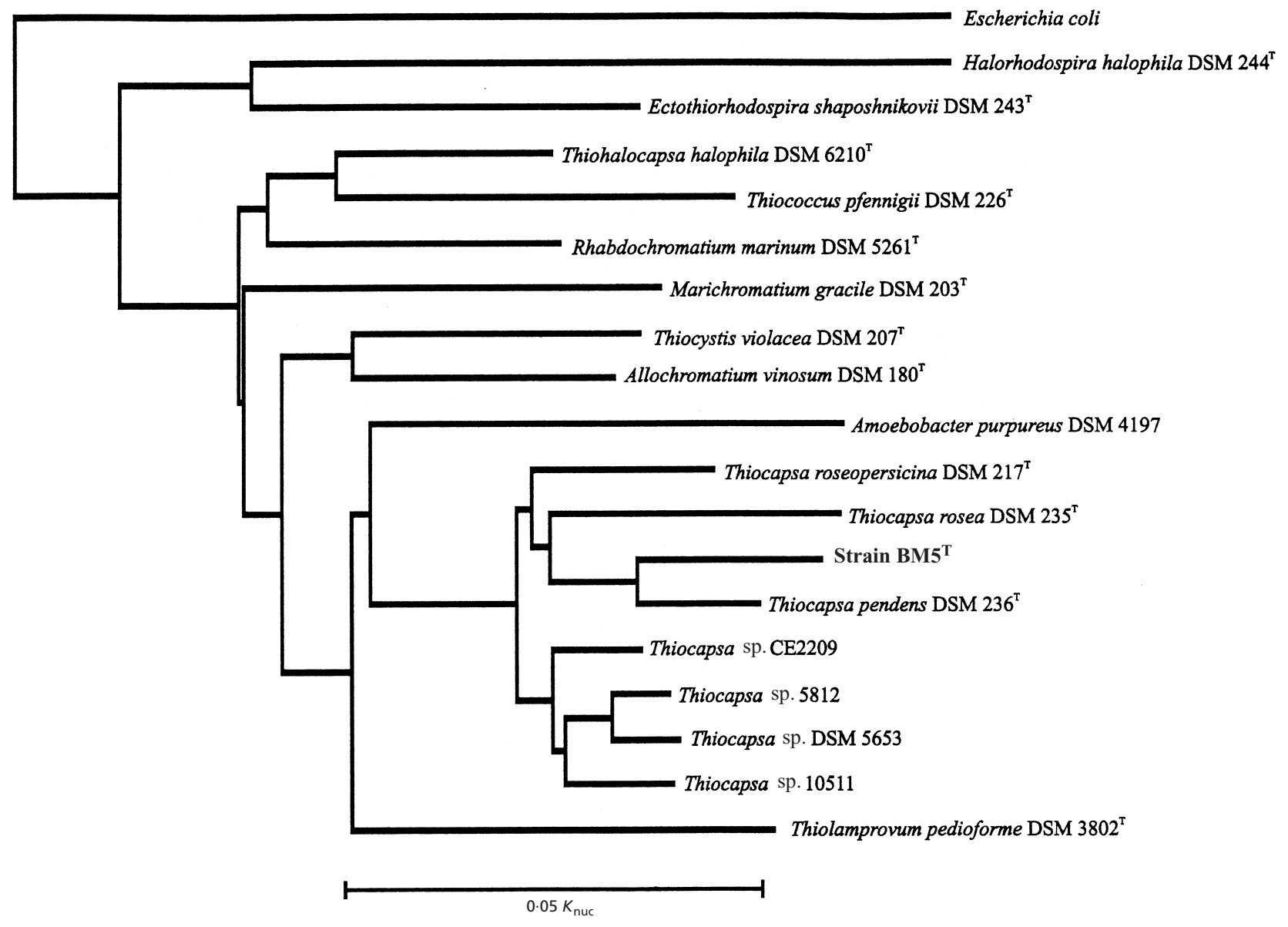

Fig. 4. Phylogenetic tree showing the relationship of strain $B M 5^{\top}$ to Thiocapsa species and other related purple sulfur bacteria. The sequence of strain $\mathrm{BM}^{\top}$ clearly clusters with those of the type strains of recognized Thiocapsa species. Bar indicates $5 \%$ estimated sequence divergence. 
The new phototrophic bacterium strain $\mathrm{BM}^{\mathrm{T}}$ is a typical member of the Chromatiaceae (Pfennig \& Trüper, 1974; Imhoff, 1984) and according to $16 \mathrm{~S}$ rDNA sequence belongs to the genus Thiocapsa (Fig. 4). Results of $16 \mathrm{~S}$ rRNA sequence analysis demonstrated that the genus Thiocapsa represents a phylogenetically closely related group which includes bacteria with and without gas vesicles (Guyoneaud et $a l ., 1998)$. Consequently, the presence of gas vesicles is no longer regarded as a genus-specific property. A number of properties of strain BM5 $5^{\mathrm{T}}$ (its ability to grow chemoautotrophically with sulfide and thiosulfate as electron donor, its occurrence in polluted shallow lagoons and its DNA G $+\mathrm{C}$ content) are in accord with other Thiocapsa species (Table 1).

Although the formation of regular cell aggregates resembles Thiopedia rosea and Thiolamprovum pedioforme (formerly 'Amoebobacter pedioformis'), strain BM5 ${ }^{\mathrm{T}}$ is clearly distinct from these two bacteria in a number of other properties (see Table 1). Strain BM5 ${ }^{\mathrm{T}}$ does not form gas vesicles as both of these bacteria do. It can use pyruvate, butyrate and valerate as does Thiopedia rosea (Pfennig, 1973; Eichler \& Pfennig, 1991), but unlike this species also grows well with propionate and lactate as substrates. In contrast to Thiopedia rosea, which does not grow under microoxic conditions in the dark (Kämpf \& Pfennig, 1980; Eichler \& Pfennig, 1991), strain BM5 ${ }^{\mathrm{T}}$ can grow chemoautotrophically with sulfide or thiosulfate as electron donor. Thiopedia rosea contains okenone as the main carotenoid, not spirilloxanthin as does strain $\mathrm{BM} 5^{\mathrm{T}}$. The optimal growth temperature of strain $\mathrm{BM} 5^{\mathrm{T}}$ is $30{ }^{\circ} \mathrm{C}$, whilst Thiopedia rosea grows at $20-25^{\circ} \mathrm{C}$. The absence of gas vesicles and the ability to photoassimilate glucose, fructose, malate, succinate, fumarate, Casamino acids and yeast extract distinguishes the new bacterium from Thiolamprovum pedioforme. The absence of gas vesicles and the ability to form typical cell arrangements distinguishes strain $\mathrm{BM} 5^{\mathrm{T}}$ from Thiocapsa pendens, which is the closest relative according to $16 \mathrm{~S}$ rDNA sequence analyses.

Unlike Thiocapsa roseopersicina, which has also been found to form cell aggregates (Pfennig \& Trüper, 1989), in strain $\mathrm{BM}^{\mathrm{T}}$ the formation of cell aggregates is a stable property in laboratory cultures if cells are grown at low light intensities (less than 2000 lux, approx. $38 \mu \mathrm{mol}$ photons $\mathrm{m}^{-2} \mathrm{~s}^{-1}$ ). Although both species appear phenotypically quite similar, they are distinguished on the basis of vitamin $\mathrm{B}_{12}$ requirement, $\mathrm{NaCl}$ optimum and utilization of butyrate and glycerol (Table 1).

On the basis of substrate utilization, formation of platelet-like cell aggregates, 16S rDNA sequences and DNA-DNA hybridization studies, this bacterium is distinct from other Thiocapsa species (Table 1, Fig. 4) and is considered as a new species of this genus for which the name Thiocapsa litoralis sp. nov. is proposed.

\section{Description of Thiocapsa litoralis sp. nov.}

Thiocapsa litoralis (li.to.ra'lis. L. adj. litoralis from the shore).

Cells are spherical and non-motile, $1.5-2.5 \mu \mathrm{m}$ in diameter and organized in regular platelets of 4,8 and 16 or even more cells. Photosynthetic membranes are of the vesicular type. The colour of cell suspensions is pink to rose-red. Bacteriochlorophyll $a$ and most probably members of the spirilloxanthin series are present as photosynthetic pigments. Phototrophic growth occurs under anoxic conditions in the light and chemoautotrophic growth is possible under microoxic conditions in the dark. Electron donors used for photoautotrophic growth are hydrogen sulfide, elemental sulfur, thiosulfate and sulfite. Globules of elemental sulfur are stored inside the cells as an intermediary product. In the presence of sulfide and bicarbonate, acetate, propionate, butyrate, valerate, pyruvate, lactate, malate, succinate, fumarate, fructose, glucose, Casamino acids and yeast extract are photoassimilated. Caprylate, tartrate, formate, ascorbate, asparaginate, benzoate, malonate, citrate, maltose, galactose, mannitol, sorbitol, glycerol, methanol and ethanol are not utilized. Assimilatory sulfate reduction occurs. Chemolithoautotrophic growth occurs with hydrogen sulfide and thiosulfate as electron donors. Vitamin $\mathrm{B}_{12}$ is required as growth factor. Storage materials are poly $\beta$-hydroxybutyrate and polyphosphates. The species is mesophilic, with optimum growth at $30^{\circ} \mathrm{C}$, at pH 6.5 and in $1 \% \mathrm{NaCl}$. The DNA $\mathrm{G}+\mathrm{C}$ content is $64.0 \mathrm{~mol} \%$ (by thermal denaturation). Isolated from microbial mat communities from the White Sea littoral shore. The type strain is $\mathrm{BM}^{\mathrm{T}}$ (=ATCC 700894). The EMBL accession number of the $16 \mathrm{~S}$ rDNA sequence of the type strain is AJ24772.

\section{ACKNOWLEDGEMENTS}

The authors would like to thank Dr A. M. Lysenko for DNA-DNA hybridization, Dr L. L. Mityushina for preparation of ultrathin sections and Dr J. Süling for DNA sequence analysis, alignment of the sequences and the construction of phylogenetic trees. This work was supported by grant 99-04-48707 from the Russian Foundation for Basic Research and a grant on 'Biodiversity'.

\section{REFERENCES}

Eichler, B. \& Pfennig, N. (1986). Characterization of a new plateforming purple sulfur-bacterium, Amoebobacter pedioformis sp. nov. Arch Microbiol 146, 295-300.

Eichler, B. \& Pfennig, N. (1991). Isolation and characteristics of Thiopedia rosea (neotype). Arch Microbiol 155, 210-216.

Felsenstein, J. (1989). PHYLIP - phylogeny inference package (version 3.2). Cladistics 5, 164-166.

Guyoneaud, R., Süling, J., Petri, R., Matheron, R., Caumette, P., Pfennig, N. \& Imhoff, J. F. (1998). Taxonomic rearrangements of the genera Thiocapsa and Amoebobacter on the basis of $16 \mathrm{~S}$ rDNA sequence analyses, and description of Thiolamprovum gen. nov. Int J Syst Bacteriol 48, 957-964. 
Imhoff, J. F. (1984). Reassignment of the genus Ectothiorhodospira Pelsh 1936 to a new family, Ectothiorhodospiraceae fam. nov., and emended description of the Chromatiaceae Bavendamm 1924. Int J Syst Bacteriol 34, 338-339.

Imhoff, J. F. (1995). Taxonomy and physiology of phototrophic purple bacteria and green sulfur bacteria. In Anoxygenic Photosynthetic Bacteria, pp. 1-15. Edited by R. E. Blankenship, M. T. Madigan \& C. E. Bauer. Dordrecht: Kluwer.

Imhoff, J. F., Süling, J. \& Petri, R. (1998). Phylogenetic relationships among the Chromatiaceae, their taxonomic reclassification and description of the new genera Allochromatium, Halochromatium, Isochromatium, Marichromatium, Thiococcus, Thiohalocapsa and Thermochromatium. Int J Syst Bacteriol 48, 1129-1143.

Jukes, T. H. \& Cantor, C. R. (1969). Evolution of protein molecules. In Mammalian Protein Metabolism, vol. 3, pp. 21-132. Edited by H. N. Munro. New York: Academic Press.

Kämpf, C. \& Pfennig, N. (1980). Capacity of Chromatiaceae for chemotrophic growth. Specific respiration rates of Thiocystis violacea and Chromatium vinosum. Arch Microbiol 127, $125-135$

Marmur, J. (1961). A procedure for the isolation of DNA from microorganisms. J Mol Biol 3, 208-218.

Owen, R. J., Hill, L. R. \& Lapage, S. P. (1969). Determination of DNA base composition from melting profiles in dilute buffers. Biopolymers 7, 503-516.
Pfennig, N. (1973). Culture and ecology of Thiopedia rosea. In Abstracts of Symposium on Prokaryotic Photosynthetic Organisms, Freiburg, Germany, pp. 75-76. Edited by G. Drews.

Pfennig, N. \& Trüper, H. G. (1974). The phototrophic bacteria. In Bergey's Manual of Determinative Bacteriology, 8th edn, pp. 24-75. Edited by R. E. Buchanan \& N. E. Gibbons. Baltimore: Williams \& Wilkins.

Pfennig, N. \& Trüper, H. G. (1989). Family Chromatiaceae. In Bergey's Manual of Systematic Bacteriology, vol. 3, pp. 1637-1653. Edited by J. T. Staley, M. P. Bryant, N. Pfennig \& J. G. Holt. Baltimore: Williams \& Wilkins.

Pfennig, N. \& Trüper, H. G. (1992). The family Chromatiaceae. In The Prokaryotes, pp. 3200-3221. Edited by A. Balows, H. G. Trüper, M. Dworkin, W. Harder \& K.-H. Schleifer. New York: Springer.

Sanger, F., Nicklen, S. \& Coulson, A. R. (1977). DNA sequencing with chain-terminating inhibitors. Proc Natl Acad Sci USA 74, 5463-5467.

Thompson, J. D., Higgins, D. G. \& Gibson, T. J. (1994). CLUSTAL W: improving the sensitivity of progressive multiple sequence alignment through sequence weighting, position-specific gap penalties and weight matrix choice. Nucleic Acids Res 22, 4673-4680.

Winogradsky, S. (1888). Zur Morphologie und Physiologie der Schwefelbakterien. In Beiträge zur Morphologie und Physiologie der Bakterien, Heft 1. Leipzig: Felix. 